\title{
Association of Lutzomyia longipalpis (Diptera: Psychodidae) population density with climate variables in Montes Claros, an area of American visceral leishmaniasis transmission in the state of Minas Gerais, Brazil
}

\author{
Érika Monteiro Michalsky ${ }^{1}$, Consuelo Latorre Fortes-Dias ${ }^{2}$, João Carlos França-Silva ${ }^{3}$, \\ Marilia Fonseca Rocha ${ }^{4}$, Ricardo Andrade Barata1, Edelberto Santos Dias ${ }^{1 /+}$ \\ ${ }^{1}$ Instituto de Pesquisas René Rachou-Fiocruz, Av. Augusto de Lima 1715, 30190-002 Belo Horizonte, MG, Brasil \\ ${ }^{2}$ Fundação Ezequiel Dias, Belo Horizonte, MG, Brasil ${ }^{3}$ Universidade Federal de Minas Gerais, Belo Horizonte, MG, Brasil \\ ${ }^{4}$ Secretaria Municipal de Saúde, Montes Claros, MG, Brasil
}

In the present paper, we evaluate the relationship between climate variables and population density of Lutzomyia longipalpis in Montes Claros, an area of active transmission of American visceral leishmaniasis (AVL) in Brazil. Entomological captures were performed in 10 selected districts of the city, between September 2002-August 2003. A total of 773 specimens of L. longipalpis were captured in the period and the population density could be associated with local climate variables (cumulative rainfall, average temperature and relative humidity) through a mathematical linear model with a determination coefficient (Rsqr) of 0.752. Although based on an oversimplified statistical analysis, as far as the vector is concerned, this approach showed to be potentially useful as a starting point to guide control measures for AVL in Montes Claros.

Key words: visceral leishmaniasis - Lutzomyia longipalpis - Montes Claros

American visceral leishmaniasis (AVL) is a zoonosis caused in Brazil by Leishmania infantum chagasi (Kinetoplastida: Trypanosomatidae) parasites that are transmitted to man through the biting of infected females of Lutzomyia longipalpis (Diptera: Psychodidae) phlebotomine sand flies. In Montes Claros, a medium-sized city in the northern region of the Minas Gerais, 25 cases of AVL were reported in 2001; this number increased to 61 cases in 2002. The average prevalence rate of canine VL in 2002 was 4.9\% in average and L. longipalpis accounted for $74 \%$ of the total of phlebotomine sand fly specimens captured in that area (Monteiro et al. 2005). In the following years, the number of reported human cases of AVL were 56 in 2003, 138 in 2004, 84 in 2005 and 55 in 2006 (MS 2009), respectively, thus characterizing Montes Claros as an area of active AVL transmission. Due to the known modulation of phlebotomine sand fly population by abiotic factors, such as climate variables, we decided to investigate the possible effect of these variables on the population density of L. longipalpis in Montes Claros (16 43'41”S, 4351'54”W) (Fig. 1).

Entomological captures were performed for three consecutive nights in one house per district, always in the last week of each month, from September 2002-August 2003, as previously described (Monteiro et al. 2005). The one-year period comprised a complete cli-

Financial support: FAPEMIG

+ Corresponding author: edel@cpqrr.fiocruz.br

Received 12 August 2009

Accepted 19 November 2009 mate cycle. L. longipalpis specimens from the 3-day captures each month in all trapping sites (independently of district, transmission profile or house location) were combined and the sum was taken as representative of the number of $L$. longipalpis captured in the respective month. The trapping sites were carefully selected based on highly similar environmental and ecological conditions, such as presence of domestic animals, fruit trees, accumulated organic matter, human population density, type of construction, landscape, elevation and other local characteristics so as to minimize any eventual interference in the results. The occurrence of human (MR Fonseca, unpublished observations) and/or canine cases of AVL (Monteiro et al. 2005) was also taken into account, as well as similar socioeconomical conditions. Districts with different AVL transmission profiles were included (Fig. 1).

Monthly climate data were collected by a conventional meteorological station of the Brazilian Institute

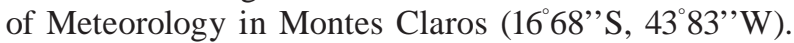
Monthly temperature (in Celsius) and relative humidity (in percentage) were provided as means of daily maximum and minimum values of each variable, respectively. Data were taken daily at 9 am-9 pm (Brasília time corresponding to 12 am-12 pm - Universal Time Coordinate), following the general procedure adopted by conventional meteorological stations. Rainfall data (in mm) refers to cumulative data.

The association between the number of $L$. longipalpis specimens (dependent variable, represented by "no. Ll”) and the independent climate variables [cumulative rainfall (rf), average temperature (tp) and average relative humidity (rh)] was investigated by multiple linear regression (best subsets and backward stepwise regres- 


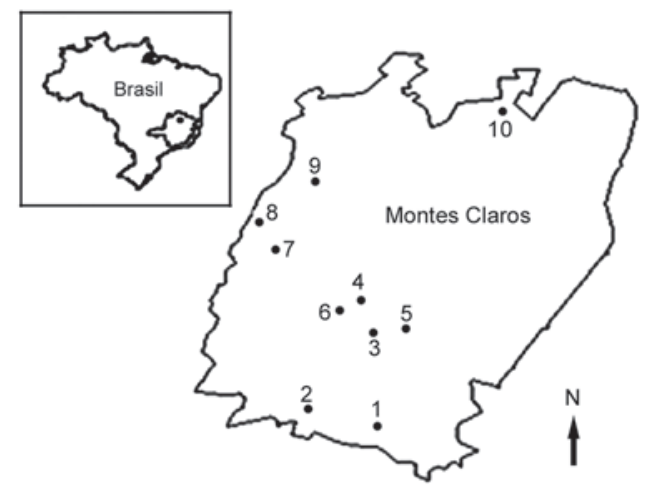

Fig. 1: geographical location of Montes Claros, in the northern region of the state of Minas Gerais, Brazil. Identification and respective American visceral leishmaniasis transmission profiles (H: high; $\mathrm{M}$ : moderate; S: sporadic) of districts where entomological captures were performed. 1: Alterosa (S); 2: Chiquinho Guimarães (M); 3: João Botelho (S); 4: Morrinhos (H); 5: Santa Rita I (H); 6: Vila Guilhermina (S); 7: Vila Mauricéia (S); 8: Vila Oliveira (S); 9: Vila São Francisco de Assis (H); 10: Village do Lago II (S). Classification criteria: high (n $\geq 4.4)$; moderate $(2.4 \leq n<4.4)$; sporadic $(n<2.4)$ where $n$ is the average number of human cases of VL in the last five years (MS 2006).

sion procedures) using the coefficient of determination (Rsqr) as the best criterion parameter of model fitness. Normality, homocedasticity and multicollinearity (expressed by the variance inflation factor) were also evaluated. The presence of interfering or outliers points was investigated by calculating Cook's distance, studentized residuals and leverage. All statistical analysis was performed using the SigmaStat ${ }^{\circledast}$ software, version 3.1.1 (Systat Software Inc, USA).

A total of 773 specimens of $L$. longipalpis were captured in the one-year period of study. Dependence analysis of the L. longipalpis population density on main local climate variables indicated that the monthly number of L. longipalpis could be predicted from a linear combination of all three climate variables and that all of them had contributed to the following descriptive equation:

$$
\begin{gathered}
\text { no. } \mathrm{Ll}=-282.550+(0.404 * \mathrm{rf})+(35.464 * \mathrm{tp})- \\
(8.549 * \mathrm{rh}) .
\end{gathered}
$$

A Rsqr of 0.752 was obtained, thereby indicating a good model fitting (Supplementary data). The model proposed passed normality and constant variance tests; multicollinearity among the independent variables was not detected, as well as any interfering or outlier point. Observed and predicted numbers of $L$. longipalpis specimens per month were close in eight out of the 12 months (Fig. 2), suggesting a reasonable association of $L$. longipalpis density with those climate variables within the period studied, as proposed by the mathematical model. Major deviations were observed in Sep/02, Oct/02, Jun/03 and Aug/03, although the predicted values for these months were within the $95 \%$ confidence intervals, except for Sep/02 (Fig. 2).

Several authors have demonstrated a clear relationship between abiotic factors (including temperature, rainfall and humidity) and the population density of phlebotomine sand flies, due to the interference in adult life cycles or to modifications in breeding sites (Scorza et al. 1968, Chaniotis et al. 1971, Roberts 1994). For L. longipalpis, humid rainy periods have been described to favor the proliferation and survival of the species (Deane \& Deane 1955). Increases in the population density of this species have been noted either during rainy months (Gomes et al. 1980, Aguiar \& Soucasaux 1984, Gomes \& Galati 1987, Salómon et al. 2002, Barata et al. 2004) or after the rainy period (Souza et al. 2004, Dias et al. 2007).

In the period of our study, the population density of L. longipalpis in Montes Claros displayed an intermittent profile, with increased densities every other month, independently of season. This was not always the case of other Brazilian cities with similar semi-arid weather


higher densities of $L$. longipalpis have been observed during the rainy season and rainfall was the major variable accounting for predicting the $L$. longipalpis captured (Barata et al. 2004, França-Silva et al. 2005). In Janaúba $\left(15^{\circ} 47^{\prime} 50^{\prime \prime} \mathrm{S}, 43^{\circ} 18^{\prime} 31^{\prime \prime} \mathrm{W}\right)$ and Várzea Grande (15'32'30'”, 56 17'18' W), marked and slight increases in population have been observed immediately after rainfall (Missawa \& Dias 2007, Michalsky et al. 2009).

Population dynamics is a very complex process that results from a conjunction of variables. The peculiar weather conditions in Montes Claros, where the climate variables follow an almost constant seasonal cycle, were tempting to offer a model proposition. However, we are aware that our statistical analysis was oversimplified and that non-parametric strategies based on discrete variables would have been more adequate. The negative coefficient for relative humidity, for instance, may be far from real. A closer analysis of the relative humidity in the four months that displayed major deviations in

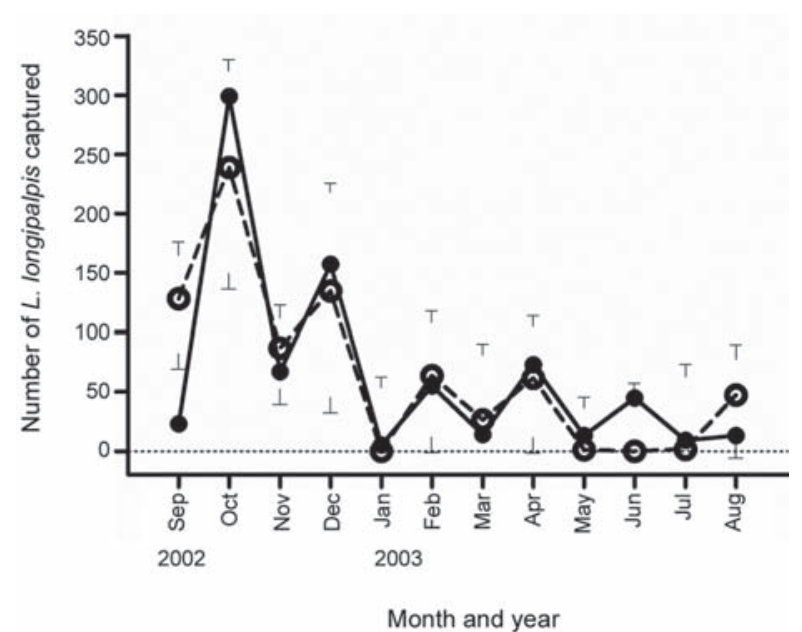

Fig. 2: prediction of Lutzomyia longipalpis monthly population (black circles/continuous line) in Montes Claros, Minas Gerais based on the model proposed. The observed values per month are in open circles/ dashed line. 95\% confidence intervals for the predicted monthly values are indicated by dashes. 
the predicted number of $L$. longipalpis showed that they shared relative humidity levels below $60 \%$. Thus, these deviations may reflect an equivocated expression of the relative humidity variable in the model.

Moreover, any mathematical model proposal should be based on a larger amount of data and would need to be validated at least by testing over longer periods of time. A main drawback to achieve that is the need of Public Health Service to introduce control measurements in such transmission areas, such as insecticide spraying. From the moment, these actions begin many other variables will arise due to environment modifications. Nevertheless, even with such limitations, we consider that an approach to a model fitting is potentially useful as a starting point, mainly in a region lacking any data to support more efficiency actions. Thus, the possibility of estimating the density of $L$. longipalpis in a given month based on predictable climate conditions may be used to guide control measures for AVL in Montes Claros as far as the vector is concerned.

\section{ACKNOWLEDGEMENTS}

To the technicians of the Centro de Controle de Zoonoses of the Secretaria da Saúde de Montes Claros.

\section{REFERENCES}

Aguiar AM, Soucasaux T 1984. Aspectos da ecologia dos flebótomos do Parque Nacional da Serra dos Órgãos, Rio de Janeiro. I. Freqüência mensal em isca humana (Díptera: Psychodidae: Phlebotominae). Mem Inst Oswaldo Cruz 79: 179-209.

Barata RA, França-Silva JC, Costa RT, Fortes-Dias CL, Silva JC, Paula EV, Prata A, Michalsky EM, Dias ES 2004. Phlebotomine sand flies in Porteirinha, an area of American leishmaniasis transmission in the state of Minas Gerais, Brazil. Mem Inst Oswaldo Cruz 99: 481-487.

Chaniotis BN, Neely JM, Correa MA, Tesh RB, Johnson KM 1971. Natural population dynamics of phlebotomine sand flies in Panama. J Med Entomol 8: 339-352.

Deane LM, Deane MP 1955. Leishmaniose visceral urbana (no cão e no homem) em Sobral, Ceará. Hospital 47: 75-87.

Dias ES, França-Silva JC, Silva JC, Monteiro EM, Gonçalves CM, Barata RA 2007. Flebotomíneos (Diptera: Psychodidae) de um foco de leishmaniose tegumentar no estado de Minas Gerais, Brasil. Rev Soc Bras Med Trop 40: 1-4.

França-Silva JC, Barata RA, Costa RT, Monteiro EM, Machado-Coelho GLL, Vieira EP, Prata A, Mayrink W, Nascimento E, Fortes-Dias CL, Silva JC, Dias ES 2005. Importance of Lutzomyia longipalpis in the dynamics of transmission of canine visceral leishmaniasis in the endemic area of Porteirinha municipality, Minas Gerais, Brazil. Vet Parasitol 131: 213-220.

Gomes AC, Galati EAB 1987. Aspectos ecológicos da leishmaniose tegumentar americana. 5. Estratificação da atividade espacial e estacional de Phlebotominae (Díptera: Psychodidae) em áreas de cultura agrícola da região de Vale do Ribeira, estado de São Paulo, Brasil. Rev Inst Med Trop Sao Paulo 82: 467-473.

Gomes AC, Rabelo EX, Santos JLF, Galati EAB 1980. Aspectos ecológicos da leishmaniose tegumentar americana. 1. Estudo experimental da freqüência de flebotomíneos em ecótopos artificiais com referência especial a Ps. intermedius. Rev Saude Publica 14: 540-546.

Michalsky EM, França-Silva JC, Barata RA, Silva FOL, Loureiro AM, Fortes-Dias CL, Dias ES 2009. Phlebotominae distribution in Janaúba, an area of transmission for visceral leishmaniasis in Brazil. Mem Inst Oswaldo Cruz 104: 56-61.

Missawa NA, Dias ES 2007. Phlebotomine sand flies (Diptera: Psychodidae) in the municipality of Várzea Grande: an area of transmission of visceral leishmaniasis in the state of Mato Grosso, Brazil. Mem Inst Oswaldo Cruz 102: 913-918.

Monteiro EM, França-Silva JC, Costa RT, Costa DC, Barata RA, Paula EV, Machado-Coelho GLL, Rocha MF, Fortes-Dias CL, Dias ES 2005. Leishmaniose visceral: estudo de flebotomíneos e infecção canina em Montes Claros, Minas Gerais. Rev Soc Bras Med Trop 38: 147-152.

MS - Ministério da Saúde 2006. Manual de vigilância e controle da leishmaniose visceral, MS, Brasília, 122 pp.

MS - Ministério da Saúde 2009. Sistema de informação de agravos de notificação da Secretaria de Vigilância em Saúde (SINAN/SVS) [homepage on the internet]. Brasil. Tabulação de dados - Leishmaniose visceral [cited 2009 Apr 12]. Available from:http://dtr2004. saude.gov.br/sinanweb/tabnet/dh?sinan/leishvi/bases/leishvbr.def

Roberts DM 1994. Arabian sand flies (Diptera: Psychodidae) prefer the hottest nights? Med Vet Entomol 8: 194-198.

Salómon OD, Rossi GC, Spinelli GR 2002. Ecological aspects of phlebotomine (Diptera: Psychodidae) in an endemic area of tegumentar leishmaniasis in the Northeastern Argentina, 1993-1998. Mem Inst Oswaldo Cruz 97: 163-168.

Scorza JV, Ortiz I, Gomez I 1968. Observaciones biologicas sobre algunos flebotomos de Rancho Grande (Venezuela). Sobre los factores microclimáticos que determinan la endemicidad de la flebotomo fauna de "Rancho Grande". Acta Biol Venez 6: 76-83.

Souza, CM, Pessanha JE, Barata RA, Michalsky EM, Costa DC, Dias ES 2004. Study on phlebotomine sand fly (Diptera: Psychodidae) fauna in Belo Horizonte, state of Minas Gerais, Brazil. Mem Inst Oswaldo Cruz 99: 795-803. 
SUPPLEMENTARY DATA

Main statistical parameters of the multiple linear regression that associates the number of Lutzomyia longipalpis specimens captured in Montes Claros (Sep/02-Aug/03) with local climate variables

\begin{tabular}{|c|c|c|c|c|}
\hline \multicolumn{5}{|c|}{ Regression parameters } \\
\hline \multirow[b]{2}{*}{ Name } & \multirow[b]{2}{*}{$\begin{array}{l}\text { Calculated } \\
\text { value }\end{array}$} & \multicolumn{3}{|c|}{ Climate variables } \\
\hline & & $\begin{array}{c}\mathrm{rf} \\
(\mathrm{mm})\end{array}$ & $\begin{array}{l}\text { tp } \\
{ }^{\circ} \mathrm{C}\end{array}$ & $\begin{array}{l}\text { rh } \\
(\%)\end{array}$ \\
\hline Rsqr & 0.752 & - & - & - \\
\hline F-to-remove & - & 5.988 & 12.81 & 15.69 \\
\hline$P$ value & - & 0.040 & 0.007 & 0.004 \\
\hline VIP & - & 1.970 & 1.236 & 2.043 \\
\hline \multicolumn{5}{|c|}{ Regression diagnostics } \\
\hline Month & \multicolumn{2}{|l|}{ Predicted } & \multicolumn{2}{|c|}{ Studentized residuals } \\
\hline Sept/02 & \multicolumn{2}{|l|}{128} & \multicolumn{2}{|c|}{-2.346} \\
\hline Oct/02 & \multicolumn{2}{|l|}{239} & \multicolumn{2}{|c|}{2.083} \\
\hline Nov/02 & \multicolumn{2}{|l|}{87} & \multicolumn{2}{|c|}{-0.423} \\
\hline Dec/02 & \multicolumn{2}{|l|}{135} & \multicolumn{2}{|c|}{0.780} \\
\hline Jan/03 & \multicolumn{2}{|l|}{$0^{a}$} & \multicolumn{2}{|c|}{0.529} \\
\hline Feb/03 & \multicolumn{2}{|l|}{64} & \multicolumn{2}{|c|}{-0.203} \\
\hline Mar/03 & \multicolumn{2}{|l|}{26} & \multicolumn{2}{|c|}{-0.308} \\
\hline Apr/03 & \multicolumn{2}{|l|}{61} & \multicolumn{2}{|c|}{0.261} \\
\hline May/03 & \multicolumn{2}{|l|}{1} & \multicolumn{2}{|c|}{0.261} \\
\hline Jun/03 & \multicolumn{2}{|l|}{$0^{a}$} & \multicolumn{2}{|c|}{1.152} \\
\hline $\mathrm{Jul} / 03$ & \multicolumn{2}{|l|}{1} & \multicolumn{2}{|c|}{0.201} \\
\hline Aug/03 & 47 & & & \\
\hline & Influence di & diagnos & & \\
\hline Month & Leverage & & Cook' & stance \\
\hline Sept/02 & 0.196 & & & \\
\hline Oct/02 & 0.666 & & & \\
\hline Nov/02 & 0.115 & & & \\
\hline Dec/02 & 0.670 & & & \\
\hline Jan/03 & 0.479 & & & \\
\hline Feb/03 & 0.247 & & & \\
\hline Mar/03 & 0.337 & & & \\
\hline Apr/03 & 0.232 & & & \\
\hline May/03 & 0.171 & & & \\
\hline Jun/03 & 0.304 & & & \\
\hline Jul/03 & 0.426 & & & \\
\hline Aug/03 & 0.157 & & & \\
\hline
\end{tabular}

Normality test: passed $(\mathrm{p}=0.340)$

Constant variance test: passed $(\mathrm{p}=0.089)$

all statistical analysis was performed with $\alpha=0.05$ and default values [4 for variance inflation factor (VIP) and Cook's distance, 2.5 for studentized residuals, 2.0 for leverage and 3.9 for F-to-remove]. $a$ : due to lacking in biological meaning, predicted negative values have been considered as zero; rf: cumulative rainfall; rh: average relative humidity; tp: average temperature. 